\title{
Ocular Manifestations of COVID-19 (SARS-CoV-2): A Critical Review of Current Literature
}

\author{
KONSTANTINOS A.A. DOUGLAS ${ }^{1,2 *}$, VIVIAN PARASKEVI DOUGLAS ${ }^{1 *}$ and MARILITA M. MOSCHOS ${ }^{2}$ \\ ${ }^{1}$ Department of Ophthalmology, Massachusetts Eye and Ear, Harvard Medical School, Boston, MA, U.S.A.; \\ ${ }^{2}$ First Department of Ophthalmology, Gennimatas General Hospital, \\ National and Kapodistrian University of Athens, School of Medicine, Athens, Greece
}

\begin{abstract}
The novel coronavirus, severe acute respiratory syndrome coronavirus 2 (SARS-CoV-2), emerged in China in the city of Wuhan in December of 2019 and since then more than 5,000,000 people have been infected, with approximately 338,000 deaths worldwide. The virus causes the coronavirus disease 2019 (COVID-19), which is characterized by fever, myalgia and cough, with severe acute respiratory syndrome being the most fearsome complication. Nevertheless, the vast majority of cases present mild symptoms or none. Central nervous system and cardiovascular manifestations have been reported. The range of ocular manifestations, either as a result of the infection or as a result of the treatment, has not yet been discussed. In this study, a systematic review of current literature relevant to COVID-19 was performed with focus on modes of transmission, ocular manifestations related to infection and medications, as well as the control of infection in ophthalmic practice.
\end{abstract}

In December 2019, a novel coronavirus (CoV), severe acute respiratory syndrome coronavirus 2 (SARS-CoV-2), emerged in China in the city of Wuhan. On March 11, 2020 the World Health Organization formally declared the COVID-19 outbreak a pandemic. The number of cases has been dramatically increasing and in the light of high contagiousness and lack of effective treatments, it is still impossible to predict how close we are or not to the end of this pandemic. As of

This article is freely accessible online.

*These Authors contributed equally to this article.

Correspondence to: Marilita Moschos, MD, Ph.D., Mesogion 154, 11527, Athens, Greece. Tel: +30 2107768321, Fax: +30 2104122139,e-mail: moschosmarilita@yahoo.fr

Key Words: COVID-19, ophthalmology, ocular manifestations, treatment, side-effects, prevention, review.
May 23, 2020, a total of 5,209,266 cases have been confirmed in more than 187 countries of which 2,056,506 have recovered while 338,121 have died (1).

SARS-CoV-2 belongs to the family of Coronaviridae, which is a large family of enveloped, positive-sense, singlestranded RNA, and to the Betacoronavirus genus of the Orthocoronaviridae subfamily. The name coronavirus

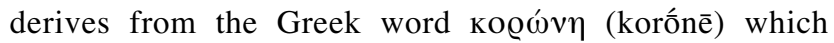
means wreath and refers to the characteristic appearance of the infective form of the virus (virions) as seen under an electron microscope, resembling a crown which is created by the bulbous surface projections of the microorganism. The Coronaviridae family has in total four genera with a wide host range, with Alphacoronavirus, Betacoronavirus infecting mammals, while Gammacoronavirus and Deltacoronavirus primarily infect birds (2). Infection with bacteria from any of these genera can lead to diverse clinical syndromes, while subclinical infections are not uncommon in all species. SARS-CoV-2 is the seventh member of the coronavirus family that is able to infect humans (3). The other six are human coronavirus 229E (Alphacoronavirus), NL63 (Alphacoronavirus), OC43 (Betacoronavirus), HKU1 (Betacoronavirus), Middle East respiratory syndrome coronavirus (MERS-CoV) (Betacoronavirus), severe acute respiratory syndrome coronavirus (SARS-CoV) (Betacoronavirus).

With regard to the life cycle of a coronavirus, infection begins when the spike glycoprotein of the viral envelope attaches to the host cell receptor and then a host protease assists the entry of the virion (either by direct fusion or endocytosis) by cleaving and activating this receptor-spike protein. This interaction is key for the life cycle of the virus and it has been confirmed that, as in SARS-CoV, angiotensinconverting enzyme II (ACE2) receptor mediates virion entry (4). It has also been demonstrated that the genome sequence of this virus is $79.6 \%$ identical to that of SARS-CoV and $96 \%$ identical at the whole-genome level to a bat coronavirus (4). 
COVID-19 diagnosis is primarily based on clinical signs and radiological findings, with laboratory findings confirming the diagnosis. With respect to ocular tissues, little is known about the pathological mechanisms. The purpose of this article is to present the ocular manifestations that have been reported so far in COVID-19-positive patients, as well as to provide a critical review of the proposed treatments of COVID-19 with focus on their ophthalmic side-effects.

\section{Epidemiology - Risk Factors}

SARS-CoV-2 cases have been confirmed across the globe except in Antarctica. In general, males and people over the age of 65 years with comorbidities are more likely to develop more severe symptoms and die when infected compared to other people without these characteristics. Even though children are affected by COVID-19 at a rate of $1 \%$ to $5 \%$ of total cases, they tend to present with milder symptoms, are less prone to severe disease and deaths are infrequent (5). Vertical intrauterine transmission from infected mothers or transmission through breastfeeding have not been confirmed. However, infected mothers can transmit the virus through either direct or indirect routes of humanto-human transmission and they are at higher risk of developing severe illness (6).

Risk factors for in-hospital death include older age, Ddimer level $>1 \mu \mathrm{g} / \mathrm{ml}$ and higher Sequential Organ Failure Assessment (SOFA) score on admission (7). In addition, patients with severe illness were more likely to have increased levels of interleukin 6 (IL-6), lactate dehydrogenase and highsensitivity cardiac troponin I, prolonged activated partial thromboplastin time (aPPT) (>90\% positive for lupus anticoagulant) (7) and reduced lymphocyte count (8). In contrast, inflammatory biomarkers and lymphocytopenia are less common findings in children (5).

\section{Routes of Transmission}

It was observed that the early cases in Wuhan were linked to the seafood market suggesting that this is likely a zoonotic disease. However, as for today the route of transmission has not yet been fully elucidated. While bats have been considered a natural host of the novel virus, as they are for a wide variety of coronaviruses, the intermediate hosts that can infect humans still remain unknown (9).

The disease is known to be directly transmitted by humanto-human contact through droplet spread (coughing or sneezing) in contact with oral, nasal and mucous membranes and indirectly through fomites i.e. in surfaces or objects that an infected person has used $(10,11)$. Of note, it has been suggested that transmission of the virus can also occur through contact with asymptomatic patients (12). In addition, the virus has been also detected on the ocular surface of
COVID-19-positive patients and in conjunctival secretions (13). Nevertheless, while in the study of Xie et al. it was shown that even conjunctivitis-free patients can actually spread the virus (14), the study of Seah et al. demonstrated no evidence of viral shedding in tears (15). The proposed theories for ocular involvement in SARS-CoV might also apply to COVID-19 and include direct inoculation of conjunctiva by droplets, migration of upper respiratory infection through the nasolacrimal duct, and hematogenous infection of lacrimal glands (16). These studies have only partially increased our understanding regarding the transmission route of SARS-CoV-2 as still it is not clear whether the virus can be transmitted through tears and if positive conjunctival titers imply higher transmissibility.

\section{Presentation - Non-ocular Manifestations}

The mean incubation period is of 5 to 6 days but affected people can experience symptoms anywhere from 2 to 12 days and only rarely after day 14 (17). Typical clinical symptoms of patients affected by COVID-19 are fever, dry cough, dyspnea, headache, pneumonia and myalgia. Nevertheless, a small fraction of patients have presented with diarrhea, hemoptysis and sputum production (18).

Diarrhea may be the only initial manifestation and fecaloral transmission has been also suggested as viral RNA has been detected at high levels in stool samples of infected individuals (19, 20). Additionally, olfactory (anosmia, phantosmia, parosmia) and taste (ageusia, dysgeusia) disorders have been also reported in case reports and small cohort studies (21-23). Anosmia of new onset is currently considered a criterion for COVID-19 assessment (24).

Regarding the neurological manifestations of patients with COVID-19, these can be classified as mild and severe. Mild symptoms include headache, dizziness, nausea/vomiting and muscle aches, while in more severe cases acute neurological events such as stroke (ischemic, hemorrhagic) and acute necrotizing encephalopathy and even altered mental status, Guillain-Barre syndrome and myelopathy have been reported (25-27).

In severe cases myocarditis, cardiac arrhythmias and heart failure have been also observed. In addition, coagulopathy is a common abnormality in COVID-19 positive patients and as a result early therapeutic anticoagulation has been suggested in ICU patients in order to prevent venous thromboembolism complications (28-30).

\section{Ocular Manifestations (Case Reports/Series)}

A retrospective study of three hospitals in Wuhan presented the neurological manifestations of 214 patients (January 16February 19, 2020). Among other important findings, this study demonstrated that $1.4 \%$ of patients (three out of 214) 
had visual impairment, without specifying the nature of the impairments (31).

In addition, $\mathrm{Wu}$ et al. performed a preliminary investigation about the prevalence of ocular manifestations in patients with COVID-19 and reported that chemosis, epiphora, and conjunctival hyperemia were present in onethird of the patients. Moreover, they observed that these manifestations most commonly occurred in patients with severe systemic disease. Even though the sample size was relatively small $(n=38)$, the study showed that white blood cell and neutrophil counts, as well as levels of procalcitonin, C-reactive protein and lactate dehydrogenase, were higher in patients who presented with ocular symptoms when compared to those without any ocular sign or symptoms. Of note, as no ophthalmic examination was performed by a specialist, clear conclusions cannot be drawn in regard to intraocular involvement or not. Overall, this study also suggested that even if only two conjunctival specimens (5.2\%) from patients with ocular abnormalities yielded positive findings for SARS-CoV-2 on reverse transcription polymerase chain reaction (RT-PCR), COVID-19 can potentially also be transmitted through the eyes (32).

Keratoconjunctivitis as initial presentation with only mild respiratory symptoms was first reported in Canada in a young patient (33). Dinkin et al. also reported two cases of ophthalmoparesis consistent with abducens nerve palsies that developed within a few days of mild respiratory symptoms associated with SARS-CoV-2 (34). In addition, neurological deficits, as well abnormal perineural or cranial nerve findings on magnetic resonance imaging were documented in both patients.

Ocular manifestations secondary to COVID-19 can even develop in the middle phase of the disease as suggested by Chen et al. (35). In their case report, a young COVID-19positive male presented with bilateral acute follicular conjunctivitis that developed 13 days after illness onset. The patient reported eye redness, excessive tearing and foreign body sensation and his examination was significant for conjunctival injection, watery discharge, inferior palpebral conjunctival follicles and palpable preauricular lymph nodes without anterior chamber inflammation or corneal defects. Viral RNA for SARS-CoV-2 was detected in conjunctival swabs (RT-PCR) on day 13. Ribavirin eye drops were administered four times a day and in less than a week (day 19), resolution of symptoms was noted and RT-PCR was negative (35).

Furthermore, pseudomembranous and hemorrhagic conjunctivitis was reported in a patient with severe COVID1919 days after the beginning of symptoms. Azithromycin along with dexamethasone eye drops and daily debridement of pseudomembrane in order to avoid conjunctival fibrosis and contraction were introduced and improvement of symptoms was noted from day 21 to day 26 (36).
Hyper-reflective lesions at the level of the inner plexiform and ganglion cell layers have been also described in COVID19-positive patients (37). Based on murine models of other CoVs, viral-induced retinitis and optic neuritis secondary to autoantibody production against neuroretina should also be included in the differential diagnosis and infected patients should be monitored for signs of neuroretinal degeneration in the long term $(16,37,38)$.

\section{Therapeutic Options Under Investigation and Potential Ocular Toxicity}

Several treatment options have been reviewed but none of these therapies have been proven effective. In general, supportive treatment which includes oxygen and mechanical ventilation is of key importance in patients presenting with severe respiratory deterioration. We should highlight that no single medication or combination has shown efficacy in humans to date. Thus, the medications discussed in this section are candidate therapies.

Remdesivir. Remdesivir (GS-5734) is a nucleotide analog which inhibits RNA-dependent RNA polymerase with broadspectrum antiviral activity. It is considered the most promising treatment so far based on its potent in vitro activity against SARS-CoV-2 but also on its in vivo and in vitro activity against SARS and MERS (39-41).

Of note, this medication was originally developed against Ebola virus (42). The first reported patient with COVID-19 in the United States received intravenous remdesivir on day 7 and clinical improvement was noted on day 8 without any adverse effects (43). The medication is currently under investigation in several clinical trials across the world and no ocular or severe adverse effects have been reported thus far (44).

Chloroquine and hydroxychloroquine. Chloroquine and hydroxychloroquine are two agents that have been widely used to treat malaria, systemic lupus erythematosus and rheumatoid arthritis. These medications have antiviral and immunomodulatory effects and are in general well tolerated. Their role in COVID-19 treatment is currently under investigation in several randomized clinical trials while recent reports have shown promising results $(45,46)$. More specifically, high doses have been recommended based on pharmacokinetic, clinical and safety studies and more typically involve an up to 10-day course of $500 \mathrm{mg}$ chloroquine twice daily chloroquine or $400 \mathrm{mg}$ of hydroxychloroquine four times daily (47).

It has been well established that chloroquine and hydroxychloroquine can result in serious, although rare, adverse effects. Long-term usage of these medications can lead to retinal toxicity but this only rarely occurs in cases with less than 10 years of usage at recommended doses (48). 
Even though the doses currently used for COVID-19 treatment can be up to five times higher than the recommended ones, it seems that the brief period of treatment course is not a concern for retinal damage and no screening is yet suggested. Nevertheless, the results of future studies or even newer recommendations may provide more useful information (49). Interestingly, the most recent observational study of Geleris et al. showed that hydroxychloroquine use was not associated with a change in risk of intubation or death (50).

Lopinavir/ritonavir. The oral combination of protease inhibitors lopinavir/ritonavir has been used for human immunodeficiency virus treatment. This antiretroviral therapy has demonstrated in vitro activity against SARSCoV-2, possibly through inhibition of 3-chymotrypsin-like protease which plays an important role in viral RNA processing. The most commonly used regimen in patients with COVID-19 patients is $400 \mathrm{mg}$ lopinavir with $100 \mathrm{mg}$ ritonavir twice daily for up to 14 days (51). There are studies which support the belief that early treatment may improve clinical outcomes $(52,53)$. Nevertheless, a randomized trial showed that this treatment was not associated with either clinical improvement or mortality in patients with severe COVID-19 (51).

There are no direct ocular side-effects in patients treated with this combination treatment. However, lopinavir/ ritonavir can lead to resurgence of autoimmune conditions such as Grave's orbitopathy due to immune reconstitution inflammatory syndrome (IRIS) (54).

Ribavirin. Ribavirin is a guanine analog that tightly binds to and inhibits SARS-CoV-2 RNA-dependent RNA polymerase. Due to inconsistent efficacy of this medication whether as a monotherapy or in combination with other drugs such as interferon in MERS and SARS, ribavirin has not been widely recommended for COVID-19. Additionally, its use has been linked to severe dose-dependent adverse events such as hematological toxicity and bradycardia, making it a less attractive option for further investigation (55). Studies have shown that there may be severe ophthalmic adverse effects associated with ribavirin, interferon or their combination, especially when treating hepatitis C-positive patients. Retinopathy, retinal vein occlusion, serous retinal detachment, non-arteritic anterior ischemic optic neuropathy (NAION), and Vogt-Koyanagi-Harada disease are among the complications of these medications that can potentially lead to irreversible visual loss (56-59).

Interferons. Interferons are a group of cytokine mediators that exhibit important antiviral activity while playing a major role in the quality of both innate and adaptive cellular immune system responses (60).
Recombinant forms of interferons have been used to treat several types of viral infections as well as neoplastic diseases. Evidence of activity of interferon $\beta$ against MERS has led interferons to be considered an alternative treatment for COVID-19, usually in combination with other medications. Studies have demonstrated that interferon $\beta 1$ is a more potent inhibitor of coronaviruses and can be a safe and promising treatment against SARS-CoV-2, and it has been suggested that its efficacy might be improved when combined with lopinavir/ritonavir, ribavirin or remdesivir $(61,62)$. Interferons have also been used in ophthalmology in a wide range of anterior and posterior chamber pathologies such as ocular surface neoplasias and macular edema $(63,64)$. Adverse ocular side-effects have been described in literature and can present either as complications during monotherapy and combined treatment as already highlighted. Besides interferon-associated retinopathy and Vogt-Koyanagi-Harada, blurred vision, ocular pain, conjunctivitis, uveitis, optic neuropathy and corneal disorders including ulcers, epithelial defects and Sjogren's syndrome, have been reported, with the more severe ones presenting after long-term treatment with interferons (65-67).

Tocilizumab. Tocilizumab is an immunomodulatory agent that has recently received FDA approval for phase III clinical trial for the treatment of critically ill COVID-19 patients. In general, this drug has been used as a monotherapy or in combination with other medications against several autoimmune diseases such as rheumatoid arthritis. In addition, in ophthalmic practice it has been recommended for the treatment of moderate or severe thyroid eye disease as well as for the treatment of giant cell arteritis $(68,69)$. In a small cohort, tocilizumab, which blocks IL-6 was tested in critically ill patients or in patients with extremely high levels of IL-6, and the study demonstrated that these patients benefited from repeated doses of oral 80-600 $\mathrm{mg}$ per administration (70). In 2012, Tada et al. first reported the occurrence of ocular adverse events in a middle-aged woman with rheumatoid arthritis who was treated with tocilizumab infusions (8 $\mathrm{mg} / \mathrm{kg}$ ) (71). More specifically, bilateral retinopathy with multifocal cotton-wool spots and retinal hemorrhages along with skin manifestations were observed 20 days after the first infusion. Gradual resolution of cutaneous and ocular findings was noted after treatment with antibiotics and corticosteroids and discontinuation of tocilizumab. The authors suggested that the abovementioned effects were secondary to modified leukocyte adhesion to vascular endothelial cells and resultant retinal capillary occlusion. Hence, it is important that ocular adverse events are always considered in patients treated with tocilizumab. 
Oseltamivir. Oseltamivir is a neuraminidase inhibitor which is widely used for the treatment of influenza. This medication was introduced early in the treatment of COVID19 patients as empirical management (influenza peak period). However, once influenza is excluded, oseltamivir is discontinued (41). Although rare, ophthalmologists should be aware of the side-effects of this medication. More specifically, Lee et al. reported a case of bilateral acute angle closure glaucoma and transient myopia after a 4-day treatment with oseltamivir. The authors postulated that these acute changes were related to the presence of cilioretinal effusion which caused anterior displacement of the lens-iris diaphragm. Moreover, cilioretinal effusion has been associated with the use of dopaminergic drugs and oseltamivir might have played a key role in the alteration of the membrane potential in the ciliary body (72).

Umifenovir. Umifenovir is an antiviral medication which inhibits spike protein-ACE2 interaction (73). It has been widely used for the treatment and prophylaxis of influenza and currently is being studied in COVID-19 patients at the same dose as for influenza (200 $\mathrm{mg} / 8 \mathrm{~h}$; per os). While umifenovir has shown promising results in small nonrandomized studies, further evaluation is needed (74). Similar to other medications, no ocular side-effects associated with its use have been reported.

Nitazoxanide. Nitazoxanide and its active metabolite tizoxanide are known to inhibit the replication of a wide range of RNA and DNA viruses. It has shown action against several viruses including SARS and MERS and currently its action against SARS-CoV-2 is under investigation either as monotherapy or in combination with hydroxychloroquine. The only reported ocular-related side-effect of nitazoxanide is eye discoloration $(75,76)$.

Favipiravir. Favipiravir is a pyrazine derivative which acts as an inhibitor of viral RNA-dependent RNA polymerase thus, preventing RNA elongation. It has been widely used and shown remarkable activity against influenza virus but also in oseltamivir-resistant cases. It is a teratogenic medication and should be avoided in pregnant women (77). However, ophthalmic side-effects have not been reported thus far. Further studies are needed in order to determine its toxicity profile.

Camostat mesylate. Camostat mesylate is a protease inhibitor that targets the host serine protease transmembrane serine protease 2 (TMPRSS2) preventing viral entry. This drug has been approved in Japan for the treatment of pancreatitis and had also demonstrated partial activity against other coronaviruses but there is no clear evidence that it can fight SARS-CoV-2 (78). No studies have reported any severe ocular side-effects other than conjunctival discoloration secondary to liver dysfunction (jaundice) (70).

Corticosteroids. Corticosteroids have been widely used for the treatment against cytokine storm syndrome which is characterized by hyperinflammation secondary to overproduction of immune cells and cytokines (80). This syndrome can occur in many infectious or autoimmune processes and a significant increase of several cytokines has been detected in a subgroup of patients with COVID-19 (81). However, the high doses and long duration which are required for treatment of severe or chronic diseases with corticosteroids can lead to a wide range of side and adverse effects including but not limited to delayed viral clearance and increased risk of secondary infection. In addition, no proven benefit has been documented so far (82). As a result, studies have focused on introducing corticosteroid-sparing medications (immunomodulatory) or alternatively using corticosteroids as adjunctive treatment in order to minimize the doses used and subsequent drug-related risks (41).

Ocular complications of corticosteroid use have been well documented. The incidence of corticosteroid-induced cataracts increases after long-term (at least 1 year) and high oral dose ( $\geq 10 \mathrm{mg} /$ day) of any type of steroid. In addition, glaucoma is another daunting complication and patients who develop glaucoma may need long-term anti-glaucoma treatment in order to control the intra-ocular pressure (83). Exogenous steroid use has been linked to the development of central serous chorioretinopathy (CSR) (84). While, this condition can be self-limiting, it can recur in up to one-third of treated patients and irreversible visual deterioration has also been reported in long-standing cases (85). Overall, it is recommended that every patient on long-term therapy with corticosteroids, regardless of route of administration and whether are prescribed or over-the-counter, should be routinely screened and offered ophthalmological evaluation (82).

Immunoglobulin therapy. Hyperimmune immunoglobulins or use of convalescent plasma have been proposed as adjunctive treatment based on the results in patients with SARS, and MERS $(86,87)$. In general, these treatments are safe although better outcomes are expected when viremia is at its peak (41). Thromboembolic events have been reported including cerebrovascular accidents, myocardial infarction and deep vein thrombosis (88).

Interestingly, iatrogenic bilateral central retinal vein occlusions were reported in a young patient who received intravenous immunoglobulins but resolved after discontinuing their administration (89). Ophthalmologists should be aware of this rare and preventable side-effect in order to minimize the incidence of visual deterioration by proposing different management plans, including dose or interval adjustments of immunoglobulins. 


\section{Prevention}

As there is clear evidence of patient-to-ophthalmologist transmission, prophylactic measures are also vital in ophthalmic practice. Efforts to contain the viral spread are of immense importance and effective containment requires a solid understanding of all possible routes of transmission, as well as timely interventions to break the chain of infection. The World Health Organization has provided guidance on the type of protection that is needed in a healthcare setting (90). Meticulous hand hygiene, use of facial and eye protection (face mask, goggles), gown and gloves are required in order to minimize transmission and exposure.

Based on the results of the clinical trials that have been published to date, no single treatment has been proven effective in increasing the likelihood of survival. More than one hundred vaccine candidates are under development, of which 78 are confirmed as being active against the novel coronavirus. However, even though all research processes have been accelerated, it is postulated that it may take up to 2 years to create a new and effective vaccine (91).

Regarding contact lens wearers, while currently there is no evidence that lenses can increase the risk of COVID-19 nor that they can provide protection against it, it is imperative for all wearers to continue strictly following appropriate hygiene practices in order to minimize the risk of infection and transmission. In fact, contact lens wearers should be encouraged to use their spectacles instead, a practice which is consistent with the guidance mainly for respiratory illnesses (92).

\section{Conclusion}

The COVID-19 pandemic has presented immense challenges worldwide. Social and physical distancing, and travel restrictions are among the strategies that have been implemented and are inevitably forcing a dramatic decline in the workforce, with negative impacts on the economy. The effect of COVID-19 on global healthcare systems is undoubtedly detrimental. There is an imperative need for multidisciplinary collaboration involving healthcare institutions, governments, pharmaceutical industries and academics in order to improve outcomes.

Even though from an ophthalmological perspective, it is essential for proper assessment of underlying ocular conditions, as medical doctors we must not forget that we are obliged towards our patients and society to provide a comprehensive evaluation of a patient's health status even beyond our field of expertise.

Accurate and early diagnosis, appropriate individualized therapeutic strategies, preventative measures and effective communication with healthcare and non-healthcare professionals are key steps for preventing further spreading of this novel coronavirus.

\section{Conflicts of Interest}

The Authors state that they have no conflicts of interest to declare.

\section{Authors' Contribution}

KAAD and VPD were involved with designing of the work, data collection, analysis and interpretation and drafting of the article. MMM supervised the study and was involved in the critical revision of the article.

\section{References}

1 Coronavirus covid-19 (2019-ncov). Available at: https://gisanddata.maps .arcgis.com/apps/opsdashboard/index.htm l\#/bda7594740fd40299423467b48e9ecf6

2 Harapan H, Itoh N, Yufika A, Winardi W, Keam S, Te H, Megawati D, Hayati Z, Wagner AL and Mudatsir M: Coronavirus disease 2019 (covid-19): A literature review. J Infect Public Heal 13(5): 667-673, 2020. DOI: 10.1016/j.jiph.2020.03.019

3 Wang H, Li X, Li T, Zhang S, Wang L, Wu X and Liu J: The genetic sequence, origin, and diagnosis of sars-cov-2. Eur J Clin Microbiol Infect Dis, 2020. PMID: 32333222. DOI: 10.1007/s10096-020-03899-4

4 Zhou P, Yang XL, Wang XG, Hu B, Zhang L, Zhang W, Si HR, Zhu Y, Li B, Huang CL, Chen HD, Chen J, Luo Y, Guo H, Jiang RD, Liu MQ, Chen Y, Shen XR, Wang X, Zheng XS, Zhao K, Chen QJ, Deng F, Liu LL, Yan B, Zhan FX, Wang YY, Xiao GF and Shi ZL: A pneumonia outbreak associated with a new coronavirus of probable bat origin. Nature 579(7798): 270-273, 2020. PMID: 32015507. DOI: 10.1038/s41586-020-2012-7

5 Ludvigsson JF: Systematic review of covid-19 in children shows milder cases and a better prognosis than adults. Acta Paediatr 109(6): 1088-1095, 2020. PMID: 32202343. DOI: 10.1111/ apa.15270

6 Karimi-Zarchi M, Neamatzadeh H, Dastgheib SA, Abbasi H, Mirjalili SR, Behforouz A, Ferdosian F and Bahrami R: Vertical transmission of coronavirus disease 19 (covid-19) from infected pregnant mothers to neonates: A review. Fetal Pediatr Pathol: 15, 2020. PMID: 32238084. DOI: 10.1080/15513815.2020. 1747120

7 Bowles L, Platton S, Yartey N, Dave M, Lee K, Hart DP, MacDonald V, Green L, Sivapalaratnam S, Pasi KJ and MacCallum P: Lupus anticoagulant and abnormal coagulation tests in patients with covid-19. N Engl J Med, 2020. PMID: 32369280. DOI: 10.1056/NEJMc2013656

8 Zhou F, Yu T, Du R, Fan G, Liu Y, Liu Z, Xiang J, Wang Y, Song B, Gu X, Guan L, Wei Y, Li H, Wu X, Xu J, Tu S, Zhang $\mathrm{Y}$, Chen $\mathrm{H}$ and Cao B: Clinical course and risk factors for mortality of adult inpatients with covid-19 in wuhan, china: A retrospective cohort study. Lancet 395(10229): 1054-1062, 2020. PMID: 32171076. DOI: 10.1016/S0140-6736(20)30566-3

9 Rothan HA and Byrareddy SN: The epidemiology and pathogenesis of coronavirus disease (covid-19) outbreak. J Autoimmun 109: 102433, 2020. PMID: 32113704. DOI: 10.1016/j.jaut.2020.102433 
10 Ong SWX, Tan YK, Chia PY, Lee TH, Ng OT, Wong MSY and Marimuthu K: Air, surface environmental, and personal protective equipment contamination by severe acute respiratory syndrome coronavirus 2 (sars-cov-2) from a symptomatic patient. JAMA 323(16): 1610-1612, 2020. PMID: 32129805. DOI: $10.1001 /$ jama.2020.3227

$11 \mathrm{Lu} \mathrm{Cw}$, Liu Xf and Jia Zf: 2019-ncov transmission through the ocular surface must not be ignored. Lancet 395(10224): E39, 2020. PMID: 32035510. DOI: 10.1016/S0140-6736(20)30313-5

12 Rothe C, Schunk M, Sothmann P, Bretzel G, Froeschl G, Wallrauch C, Zimmer T, Thiel V, Janke C, Guggemos W, Seilmaier M, Drosten C, Vollmar P, Zwirglmaier K, Zange S, Wölfel R and Hoelscher M: Transmission of 2019-ncov infection from an asymptomatic contact in Germany. N Engl J Med 382(10): 970-971, 2020. PMID: 32003551. DOI: 10.1056/NEJMc2001468

13 Xia J, Tong J, Liu M, Shen Y and Guo D: Evaluation of coronavirus in tears and conjunctival secretions of patients with sars-cov-2 infection. J Med Virol, 2020. PMID: 32100876. DOI: $10.1002 /$ jmv .25725

14 Xie HT, Jiang SY, Xu KK, Liu X, Xu B, Wang L and Zhang MC: Sars-cov-2 in the ocular surface of covid-19 patients. Eye Vis (Lond) 7: 23, 2020. PMID: 32355863. DOI: 10.1186/s40662-020-00189-0

15 Seah IYJ, Anderson DE, Kang AEZ, Wang L, Rao P, Young BE, Lye DC and Agrawal R: Assessing viral shedding and infectivity of tears in coronavirus disease 2019 (covid-19) patients. Ophthalmology, 2020. PMID: 32291098. DOI: 10.1016/ j.ophtha.2020.03.026

16 Seah I and Agrawal R: Can the coronavirus disease 2019 (covid19) affect the eyes? A review of coronaviruses and ocular implications in humans and animals. Ocul Immunol Inflamm 28(3): 391-395, 2020. PMID: 32175797. DOI: 10.1080/0927 3948.2020.1738501

17 Marinho PM, Marcos AAA, Romano AC, Nascimento H and Belfort R, Jr.: Retinal findings in patients with covid-19. Lancet 395(10237): 1610, 2020. PMID: 32405105. DOI: 10.1016/S0140-6736(20)31014-X

18 Wang Y, Detrick B, Yu Z-X, Zhang J, Chesky L and Hooks JJ: The role of apoptosis within the retina of coronavirus-infected mice. Invest Ophthalmol Vis Sci 41(10): 3011-3018, 2000. PMID: 10967058.

19 Lauer SA, Grantz KH, Bi Q, Jones FK, Zheng Q, Meredith HR, Azman AS, Reich NG and Lessler J: The incubation period of coronavirus disease 2019 (covid-19) from publicly reported confirmed cases: Estimation and application. Ann Intern Med 172(9): 577-582, 2020. PMID: 32150748. DOI: 10.7326/M20-0504

20 Huang C, Wang Y, Li X, Ren L, Zhao J, Hu Y, Zhang L, Fan G, Xu J, Gu X, Cheng Z, Yu T, Xia J, Wei Y, Wu W, Xie X, Yin W, Li H, Liu M, Xiao Y, Gao H, Guo L, Xie J, Wang G, Jiang R, Gao Z, Jin Q, Wang J and Cao B: Clinical features of patients infected with 2019 novel coronavirus in wuhan, china. Lancet 395(10223): 497-506, 2020. PMID: 31986264. DOI: 10.1016/S0140-6736(20)30183-5

21 Wolfel R, Corman VM, Guggemos W, Seilmaier M, Zange S, Muller MA, Niemeyer D, Jones TC, Vollmar P, Rothe C, Hoelscher M, Bleicker T, Brunink S, Schneider J, Ehmann R, Zwirglmaier K, Drosten C and Wendtner C: Virological assessment of hospitalized patients with covid-2019. Nature, 2020. PMID: 32235945. DOI: 10.1038/s41586-020-2196-x
$22 \mathrm{Li} \mathrm{YC}$, Bai WZ and Hashikawa T: The neuroinvasive potential of sars-cov2 may be at least partially responsible for the respiratory failure of covid-19 patients. J Med Virol, 2020. PMID: 32104915. DOI: 10.1002/jmv.25728

23 Giacomelli A, Pezzati L, Conti F, Bernacchia D, Siano M, Oreni L, Rusconi S, Gervasoni C, Ridolfo AL, Rizzardini G, Antinori $\mathrm{S}$ and Galli M: Self-reported olfactory and taste disorders in sars-cov-2 patients: A cross-sectional study. Clin Infect Dis, 2020. PMID: 32215618. DOI: $10.1093 / \mathrm{cid} / \mathrm{ciaa} 330$

24 Eliezer M, Hautefort C, Hamel AL, Verillaud B, Herman P, Houdart E and Eloit C: Sudden and complete olfactory loss function as a possible symptom of covid-19. JAMA Otolaryngol Head Neck Surg, 2020. PMID: 32267483. DOI: 10.1001/jamaoto.2020.0832

25 Vaira LA, Salzano G, Deiana G and De Riu G: Anosmia and ageusia: Common findings in covid-19 patients. Laryngoscope, 2020. PMID: 32237238. DOI: 10.1002/lary.28692

26 Temmel AF, Quint C, Schickinger-Fischer B, Klimek L, Stoller $\mathrm{E}$ and Hummel $\mathrm{T}$ : Characteristics of olfactory disorders in relation to major causes of olfactory loss. Arch Otolaryngol Head Neck Surg 128(6): 635-641, 2002. PMID: 12049556. DOI: 10.1001/archotol.128.6.635

27 Li Y, Wang M, Zhou Y, Chang J, Xian Y, Mao L, Hong C, Chen $\mathrm{S}$, Wang $\mathrm{Y}$, Wang $\mathrm{H}$, $\mathrm{Li} \mathrm{M}$, Jin $\mathrm{H}$ and $\mathrm{Hu} \mathrm{B}$ : Acute cerebrovascular disease following covid-19: A single center, retrospective, observational study. SSRN, 2020. PMID: 32345579. DOI: $10.2139 /$ ssrn.3550025

28 Mao L, Wang M, Chen S, He Q, Chang J, Hong C, Zhou Y, Wang D, Miao X, Hu Y, Li Y, Jin H and Hu B: Neurological manifestations of hospitalized patients with covid-19 in wuhan, china: A retrospective case series study. SSRN, 2020. PMID: 32275288. DOI: $10.2139 / \mathrm{ssrn} .3544840$

29 Poyiadji N, Shahin G, Noujaim D, Stone M, Patel S and Griffith B: Covid-19-associated acute hemorrhagic necrotizing encephalopathy: Ct and mri features. Radiology 201187, 2020. PMID: 32228363. DOI: 10.1148/radiol.2020201187

30 Bonow RO, Fonarow GC, O'Gara PT and Yancy CW: Association of coronavirus disease 2019 (covid-19) with myocardial injury and mortality. JAMA Cardiol, 2020. PMID: 32219362. DOI: $10.1001 /$ jamacardio.2020.1105

31 Wang D, Hu B, Hu C, Zhu F, Liu X, Zhang J, Wang B, Xiang $\mathrm{H}$, Cheng Z, Xiong Y, Zhao Y, Li Y, Wang X and Peng Z: Clinical characteristics of 138 hospitalized patients with 2019 novel coronavirus-infected pneumonia in wuhan, china. JAMA, 2020. PMID: 32031570. DOI: 10.1001/jama.2020.1585

32 Llitjos JF, Leclerc M, Chochois C, Monsallier JM, Ramakers M, Auvray $\mathrm{M}$ and Merouani $\mathrm{K}$ : High incidence of venous thromboembolic events in anticoagulated severe covid-19 patients. J Thromb Haemost, 2020. PMID: 32320517. DOI: $10.1111 /$ jth. 14869

33 Mao L, Jin H, Wang M, Hu Y, Chen S, He Q, Chang J, Hong C, Zhou Y, Wang D, Miao X, Li Y and Hu B: Neurologic manifestations of hospitalized patients with coronavirus disease 2019 in wuhan, china. JAMA Neurol, 2020. PMID: 32275288. DOI: 10.1001/jamaneurol.2020.1127

$34 \mathrm{Wu}$ P, Duan F, Luo C, Liu Q, Qu X, Liang L and Wu K: Characteristics of ocular findings of patients with coronavirus disease 2019 (covid-19) in hubei province, china. JAMA Ophthalmol, 2020. PMID: 32232433. DOI: 10.1001/jamaophthal mol.2020.1291 
35 Cheema M, Aghazadeh H, Nazarali S, Ting A, Hodges J, McFarlane A, Kanji JN, Zelyas N, Damji KF and Solarte C: Keratoconjunctivitis as the initial medical presentation of the novel coronavirus disease 2019 (covid-19). Can J Ophthalmol, 2020. PMID: 32284146. DOI: 10.1016/j.jcjo.2020.03.003

36 Dinkin M, Gao V, Kahan J, Bobker S, Simonetto M, Wechsler P, Harpe J, Greer C, Mints G, Salama G, Tsiouris AJ and Leifer D: Covid-19 presenting with ophthalmoparesis from cranial nerve palsy. Neurology, 2020. PMID: 32358218. DOI: 10.1212/WNL.0000000000009700

37 Chen L, Liu M, Zhang Z, Qiao K, Huang T, Chen M, Xin N, Huang Z, Liu L, Zhang G and Wang J: Ocular manifestations of a hospitalised patient with confirmed 2019 novel coronavirus disease. Br J Ophthalmol 104(6): 748-751, 2020. PMID: 32265202. DOI: 10.1136/bjophthalmol-2020-316304

38 Navel V, Chiambaretta F and Dutheil F: Haemorrhagic conjunctivitis with pseudomembranous related to sars-cov-2. Am J Ophthalmol Case Rep 100735, 2020. PMID: 32377594. DOI: 10.1016/j.ajoc.2020.100735

39 Sheahan TP, Sims AC, Graham RL, Menachery VD, Gralinski LE, Case JB, Leist SR, Pyrc K, Feng JY, Trantcheva I, Bannister R, Park Y, Babusis D, Clarke MO, Mackman RL, Spahn JE, Palmiotti CA, Siegel D, Ray AS, Cihlar T, Jordan R, Denison MR and Baric RS: Broad-spectrum antiviral gs-5734 inhibits both epidemic and zoonotic coronaviruses. Sci Transl Med 9(396), 2017. PMID: 28659436. DOI: 10.1126/scitranslmed. aal3653

40 Agostini ML, Andres EL, Sims AC, Graham RL, Sheahan TP, Lu X, Smith EC, Case JB, Feng JY, Jordan R, Ray AS, Cihlar T, Siegel D, Mackman RL, Clarke MO, Baric RS and Denison MR: Coronavirus susceptibility to the antiviral remdesivir (gs5734 ) is mediated by the viral polymerase and the proofreading exoribonuclease. mBio 9(2), 2018. PMID: 29511076. DOI: 10.1128/mBio.00221-18

41 Sanders JM, Monogue ML, Jodlowski TZ and Cutrell JB: Pharmacologic treatments for coronavirus disease 2019 (covid19): A review. JAMA, 2020. PMID: 32282022. DOI: 10.1001/jama.2020.6019

42 Mulangu S, Dodd LE, Davey RT, Jr., Tshiani Mbaya O, Proschan M, Mukadi D, Lusakibanza Manzo M, Nzolo D, Tshomba Oloma A, Ibanda A, Ali R, Coulibaly S, Levine AC, Grais R, Diaz J, Lane HC, Muyembe-Tamfum JJ, Group PW, Sivahera B, Camara M, Kojan R, Walker R, Dighero-Kemp B, Cao H, Mukumbayi P, Mbala-Kingebeni P, Ahuka S, Albert S, Bonnett T, Crozier I, Duvenhage M, Proffitt C, Teitelbaum M, Moench T, Aboulhab J, Barrett K, Cahill K, Cone K, Eckes R, Hensley L, Herpin B, Higgs E, Ledgerwood J, Pierson J, Smolskis M, Sow Y, Tierney J, Sivapalasingam S, Holman W, Gettinger N, Vallee D, Nordwall $J$ and Team PCS: A randomized, controlled trial of ebola virus disease therapeutics. N Engl J Med 381(24): 2293-2303, 2019. PMID: 31774950. DOI: 10.1056/NEJMoa1910993

43 Holshue ML, DeBolt C, Lindquist S, Lofy KH, Wiesman J, Bruce H, Spitters C, Ericson K, Wilkerson S, Tural A, Diaz G, Cohn A, Fox L, Patel A, Gerber SI, Kim L, Tong S, Lu X, Lindstrom S, Pallansch MA, Weldon WC, Biggs HM, Uyeki TM, Pillai SK and Washington State -nCo VCIT: First case of 2019 novel coronavirus in the united states. N Engl J Med 382(10): 929-936, 2020. PMID: 32004427. DOI: 10.1056/NEJMoa2001191
44 Study to evaluate the safety and antiviral activity of remdesivir (gs-5734 ${ }^{\mathrm{TM}}$ ) in participants with severe coronavirus disease (covid-19) - full text view - clinicaltrials.Gov. Available at: https://clinicaltrials.gov/ct2/show/NCT04292899

45 Chloroquine diphosphate for the treatment of severe acute respiratory syndrome secondary to sars-cov2 - full text view clinicaltrials.Gov. Available at: https://clinicaltrials.gov/ct2/ show/NCT04323527? term $=$ chloroquine $\&$ draw $=2 \&$ rank $=2$

46 Hydroxychloroquine for the treatment of mild covid-19 disease - full text view - clinicaltrials.Gov. Available at: https://clinicaltrials.gov/ct2/show/NCT04340544?term=hydroxyc hloroquine $\&$ draw $=2 \&$ rank $=6$

47 Gautret P, Lagier JC, Parola P, Hoang VT, Meddeb L, Mailhe M, Doudier B, Courjon J, Giordanengo V, Vieira VE, Dupont HT, Honore S, Colson P, Chabriere E, La Scola B, Rolain JM, Brouqui $\mathrm{P}$ and Raoult D: Hydroxychloroquine and azithromycin as a treatment of covid-19: Results of an open-label nonrandomized clinical trial. Int J Antimicrob Agents 105949, 2020. PMID: 32205204. DOI: 10.1016/j.ijantimicag.2020.105949

48 Costedoat-Chalumeau N, Dunogué B, Leroux G, Morel N, Jallouli M, Le Guern V, Piette JC, Brézin AP, Melles RB and Marmor MF: A critical review of the effects of hydroxychloroquine and chloroquine on the eye. Clin Rev Allergy Immunol 49(3): 317-326, 2015. PMID: 25672591. DOI: 10.1007/s12016015-8469-8

49 Marmor MF: Covid-19 and chloroquine/hydroxychloroquine: Is there ophthalmological concern? Am J Ophthalmol 213: A3-A4, 2020. PMID: 32247518. DOI: 10.1016/j.ajo.2020.03.028

50 Geleris J, Sun Y, Platt J, Zucker J, Baldwin M, Hripcsak G, Labella A, Manson D, Kubin C, Barr RG, Sobieszczyk ME and Schluger NW: Observational study of hydroxychloroquine in hospitalized patients with covid-19. N Engl J Med, 2020. PMID: 32379955. DOI: 10.1056/NEJMoa2012410

51 Cao B, Wang Y, Wen D, Liu W, Wang J, Fan G, Ruan L, Song B, Cai Y, Wei M, Li X, Xia J, Chen N, Xiang J, Yu T, Bai T, Xie X, Zhang L, Li C, Yuan Y, Chen H, Li H, Huang H, Tu S, Gong F, Liu Y, Wei Y, Dong C, Zhou F, Gu X, Xu J, Liu Z, Zhang Y, Li H, Shang L, Wang K, Li K, Zhou X, Dong X, Qu Z, Lu S, Hu X, Ruan S, Luo S, Wu J, Peng L, Cheng F, Pan L, Zou J, Jia C, Wang J, Liu X, Wang S, Wu X, Ge Q, He J, Zhan H, Qiu F, Guo L, Huang C, Jaki T, Hayden FG, Horby PW, Zhang D and Wang C: A trial of lopinavir-ritonavir in adults hospitalized with severe covid-19. N Engl J Med 382(19): 1787-1799, 2020. PMID: 32187464. DOI: 10.1056/NEJMoa 2001282

52 Chan KS, Lai ST, Chu CM, Tsui E, Tam CY, Wong MML, Tse MW, Que TL, Peiris JSM, Sung J, Wong VCW and Yuen KY: Treatment of severe acute respiratory syndrome with lopinavir/ritonavir: A multicentre retrospective matched cohort study. Hong Kong Med J 9(6): 399-406, 2003. PMID: 14660806.

53 Yao TT, Qian JD, Zhu WY, Wang Y and Wang GQ: A systematic review of lopinavir therapy for sars coronavirus and mers coronavirus - a possible reference for coronavirus disease-19 treatment option. J Med Virol 92(6): 556-563, 2020. PMID: 32104907. DOI: $10.1002 /$ jmv.25729

54 Nallu R, Madhavan P, Chirch L and Luthra P: Thyroid eye disease due to immune reconstitution inflammatory syndrome as a consequence of antiretroviral therapy in the setting of aids. Case Rep Endocrinol 2020: 1728423, 2020. PMID: 32099691. DOI: $10.1155 / 2020 / 1728423$ 
55 Zhong H, Wang Y, Zhang Z-L, Liu Y-X, Le K-J, Cui M, Yu YT, Gu Z-C, Gao Y and Lin H-W: Efficacy and safety of current therapeutic options for covid-19-lessons to be learnt from sars and mers epidemic: A systematic review and meta-analysis Pharmacol Res 104872, 2020. PMID: 32360583. DOI: 10.1016/j.phrs.2020.104872

56 Modorati G, Matteo DF, Miserocchi E, Colucci A and Bandello F: Serous retinal detachments complicating interferon-alpha and ribavirin treatment in patients with hepatitis c. Case Rep Ophthalmol 2(1): 105-110, 2011. PMID: 22110438. DOI: $10.1159 / 000326747$

57 O’Day R, Gillies MC and Ahlenstiel G: Ophthalmologic complications of antiviral therapy in hepatitis c treatment. World J Gastroenterol 19(45): 8227-8237, 2013. PMID: 24363513. DOI: $10.3748 /$ wjg.v19.i45.8227

58 Chis BA, Nicula C and Dumitrascu D: Early optic neuropathy during pegylated alfa 2-b interferon and ribavirin hcv treatment. A case report. Med Pharm Rep 92(3): 308-310, 2019. PMID: 31460516. DOI: $10.15386 / \mathrm{mpr}-1316$

59 Duan J, Wang Y, Liu D and Ma J: Induction of vogt-koyanagiharada disease by interferon-alpha and ribavirin treatment in patients with hepatitis c: A case report and review of the literature. Ocul Immunol Inflamm 27(2): 229-234, 2019. PMID: 29023176. DOI: $10.1080 / 09273948.2017 .1373827$

60 Le Page C, Génin P, Baines MG and Hiscott J: Interferon activation and innate immunity. Rev Immunogenet 2(3): 374386, 2000. PMID: 11256746.

61 Sheahan TP, Sims AC, Leist SR, Schafer A, Won J, Brown AJ, Montgomery SA, Hogg A, Babusis D, Clarke MO, Spahn JE, Bauer L, Sellers S, Porter D, Feng JY, Cihlar T, Jordan R, Denison MR and Baric RS: Comparative therapeutic efficacy of remdesivir and combination lopinavir, ritonavir, and interferon beta against mers-cov. Nat Commun 11(1): 222, 2020. PMID: 31924756. DOI: 10.1038/s41467-019-13940-6

62 Sallard E, Lescure FX, Yazdanpanah Y, Mentre F and PeifferSmadja N: Type 1 interferons as a potential treatment against covid-19. Antiviral Res 178: 104791, 2020. PMID: 32275914. DOI: $10.1016 /$ j.antiviral.2020.104791

63 Shah SU, Kaliki S, Kim HJ, Lally SE, Shields JA and Shields CL: Topical interferon alfa- $2 b$ for management of ocular surface squamous neoplasia in 23 cases: Outcomes based on american joint committee on cancer classification. Arch Ophthalmol 130(2): 159-164, 2012. PMID: 22332208. DOI: 10.1001/archophthalmol.2011.385

64 Deuter CM, Koetter I, Guenaydin I, Stuebiger N and Zierhut M: Interferon alfa-2a: A new treatment option for long lasting refractory cystoid macular edema in uveitis? A pilot study. Retina 26(7): 786-791, 2006. PMID: 16963852. DOI: 10.1097/01.iae.0000244265.75771.71

65 Liu Y-T, Chen K-H and Hsu W-M: Sterile corneal ulcer andsjogren's syndrome associated with long-term interferon alpha- $2 \mathrm{~b}$ treatment in a case of multiple myeloma. Int J Biomed Sci2(3): 299-301, 2006. PMID: 23674995.

66 Fraunfelder FW and Fraunfelder FT: Interferon alfaassociatedanterior ischemic optic neuropathy. Ophthalmology 118(2): 408-411 e401-402, 2011. PMID: 20630599. DOI: 10.1016/j.ophtha.2010.03.063

67 Lewczuk N, Zdebik A and Bogusławska J: Interferon alpha 2a and 2b in ophthalmology: A review. J Interferon Cytokine Res 39(5): 259-272, 2019. PMID: 30950678. DOI: 10.1089/jir.2018.0125
68 Sy A, Eliasieh K and Silkiss RZ: Clinical response to tocilizumab in severe thyroid eye disease. Ophthalmic Plast Reconstr Surg 33(3): e55-e57, 2017. PMID: 27281483. DOI: 10.1097/IOP.0000000000000730

69 Stone JH, Tuckwell K, Dimonaco S, Klearman M, Aringer M, Blockmans D, Brouwer E, Cid MC, Dasgupta B, Rech J, Salvarani C, Schett G, Schulze-Koops H, Spiera R, Unizony SH and Collinson N: Trial of tocilizumab in giant-cell arteritis. N Engl J Med 377(4): 317-328, 2017. PMID: 28745999. DOI: 10.1056/NEJMoa1613849

70 Luo P, Liu Y, Qiu L, Liu X, Liu D and Li J: Tocilizumab treatment in covid-19: A single center experience. J Med Virol, 2020. PMID: 32253759. DOI: 10.1002/jmv.25801

71 Tada A, Hashida N, Tanaka T and Nishida K: Anti-interleukin-6 receptor antibody therapy-induced retinopathy in a patient with rheumatoid arthritis. Case Rep Rheumatol 2012: 270315, 2012. PMID: 23424706. DOI: 10.1155/2012/270315

72 Lee JW, Lee JE, Choi HY and Lee JS: Oseltamivir (tamiflu)induced bilateral acute angle closure glaucoma and transient myopia. Indian J Ophthalmol 62(12): 1165-1167, 2014. PMID: 23571265. DOI: $10.4103 / 0301-4738.109531$

73 Kadam RU and Wilson IA: Structural basis of influenza virus fusion inhibition by the antiviral drug arbidol. Proc Natl Acad Sci USA 114(2): 206-214, 2017. PMID: 28003465. DOI: 10.1073/pnas.1617020114

74 Wang Z, Yang B, Li Q, Wen L and Zhang R: Clinical features of 69 cases with coronavirus disease 2019 in wuhan, china. Clin Infect Dis, 2020. PMID: 32176772. DOI: 10.1093/cid/ciaa272

75 Treatment with hydroxychloroquine $v s$ nitazoxanide + hydroxychloroquine in patients with covid-19 with risk factors for poor outcome (2020). Available at: https://clinicaltrials.gov/ ct $2 /$ show/NCT04341493

76 Alinia ${ }^{\circledR}$ (nitazoxanide) tablets (nitazoxanide) for oral suspension. Available at: https://www.accessdata.fda.gov/ drugsatfda_docs/label/2005/0218181bl.pdf

77 Furuta Y, Komeno T and Nakamura T: Favipiravir (t-705), a broad spectrum inhibitor of viral rna polymerase. Proc Jpn Acad Ser B Phys Biol Sci 93(7): 449-463, 2017. PMID: 28769016. DOI: $10.2183 /$ pjab.93.027

78 Hoffmann M, Kleine-Weber H, Schroeder S, Kruger N, Herrler T, Erichsen S, Schiergens TS, Herrler G, Wu NH, Nitsche A, Muller MA, Drosten C and Pohlmann S: Sars-cov-2 cell entry depends on ace 2 and tmprss 2 and is blocked by a clinically proven protease inhibitor. Cell 181(2): 271-280 e278, 2020. PMID: 32142651. DOI: $10.1016 /$ j.cell.2020.02.052

79 Foipan ${ }^{\circledR}$ tablets $100 \mathrm{mg}$. Available at: http://www.shijiebia opin.net/upload/product/201272318373223.PDF

80 Mehta P, McAuley DF, Brown M, Sanchez E, Tattersall RS and Manson JJ: Covid-19: Consider cytokine storm syndromes and immunosuppression. Lancet 395(10229): 1033-1034, 2020. PMID: 32192578. DOI: 10.1016/S0140-6736(20)30628-0

81 Yang Y, Shen C, Li J, Yuan J, Yang M, Wang F, Li G, Li Y, Xing L, Peng L, Wei J, Cao M, Zheng H, Wu W, Zou R, Li D, Xu Z, Wang $\mathrm{H}$, Zhang $\mathrm{M}$, Zhang Z, Liu L and Liu Y: Exuberant elevation of ip-10, mcp-3 and il-1ra during sars-cov-2 infection is associated with disease severity and fatal outcome. medRxiv, 2020. DOI: $10.1101 / 2020.03 .02 .20029975$

82 Renfro L and Snow JS: Ocular effects of topical and systemic steroids. Dermatol Clin 10(3): 505-512, 1992. PMID: 1617809. DOI: $10.1016 / \mathrm{s} 0733-8635(18) 30318-8$ 
83 Chadha V, Cruickshank I, Swingler R and Sanders R: Advanced glaucomatous visual loss and oral steroids. BMJ 337(7679): a670, 2008. PMID: 18676441. DOI: 10.1136/bmj.a670

84 Bouzas EA, Karadimas P and Pournaras CJ: Central serous chorioretinopathy and glucocorticoids. Surv Ophthalmol 47(5): 431-448, 2002. PMID: 12431693. DOI: 10.1016/S00396257(02)00338-7

85 Liew G, Quin G, Gillies M and Fraser-Bell S: Central serous chorioretinopathy: A review of epidemiology and pathophysiology. Clin Exp Ophthalmol 41(2): 201-214, 2013. PMID: 22788735. DOI: $10.1111 / j .1442-9071.2012 .02848 . x$

86 Soo YO, Cheng Y, Wong R, Hui DS, Lee CK, Tsang KK, Ng $\mathrm{MH}$, Chan P, Cheng G and Sung JJ: Retrospective comparison of convalescent plasma with continuing high-dose methylprednisolone treatment in sars patients. Clin Microbiol Infect 10(7): 676-678, 2004. PMID: 15214887. DOI: 10.1111/j.1469-0691.2004.00956.x

87 Arabi Y, Balkhy H, Hajeer AH, Bouchama A, Hayden FG, AlOmari A, Al-Hameed FM, Taha Y, Shindo N, Whitehead J, Merson L, AlJohani S, Al-Khairy K, Carson G, Luke TC, Hensley L, Al-Dawood A, Al-Qahtani S, Modjarrad K, Sadat M, Rohde G, Leport C and Fowler R: Feasibility, safety, clinical, and laboratory effects of convalescent plasma therapy for patients with middle east respiratory syndrome coronavirus infection: A study protocol. Springerplus 4: 709, 2015. PMID: 26618098. DOI: 10.1186/s40064-015-1490-9
88 Orbach H, Katz U, Sherer Y and Shoenfeld Y: Intravenous immunoglobulin: Adverse effects and safe administration. Clin Rev Allergy Immunol 29(3): 173-184, 2005. PMID: 16391392. DOI: $10.1385 / C R I A I: 29: 3: 173$

89 Oh KT, Boldt HC and Danis RP: Iatrogenic central retinal vein occlusion and hyperviscosity associated with high-dose intravenous immunoglobulin administration. Am J Ophthalmol 124(3): 416-418, 1997. PMID: 9439378. DOI: 10.1016/s00029394(14)70844-x

90 World Health Organization: Rational use of personal protective equipment (PPE) for coronavirus disease (COVID-19). Available at: https://apps.who.int/iris/bitstream/handle/10665/331498/ WHO-2019-nCoV-IPCPPE_use-2020.2-eng.pdf

91 Thanh Le T, Andreadakis Z, Kumar A, Gomez Roman R, Tollefsen S, Saville M and Mayhew S: The covid-19 vaccine development landscape. Nat Rev Drug Discov 19(5): 305-306, 2020. PMID: 32273591. DOI: 10.1038/d41573-020-00073-5

92 Jones L, Walsh K, Willcox M, Morgan P and Nichols J: The covid-19 pandemic: Important considerations for contact lens practitioners. Cont Lens Anterior Eye 43(3): 196-203, 2020. PMID: 32273245. DOI: 10.1016/j.clae.2020.03.012

Received May 12, 2020

Revised May 24, 2020

Accepted May 28, 2020 